\title{
Problems and Suggestions of Agricultural Information Service System Construction-Taking Hubei Province as an Example
}

\author{
ChenQian \\ Wuhan Donghu University, Wuhan, Hubei, China \\ chenqian@163.com
}

Keywords: agricultural information service; Hubei province; problems and suggestions

\begin{abstract}
The agricultural research departments of our country have already obtained many good results in many areas of information service since 1980s. However, there are still some problems in the construction of agricultural information service system in Hubei province. This paper gives three suggestions, which are to emphasize infrastructure construction, to improve staff science education quality and to construct information sharing mechanism in order to speed up the construction of the agricultural information service system in Hubei province.
\end{abstract}

\section{Concept of Agricultural Information Service}

The concept of "the agricultural information service" was introduced into China in 1980s. The agricultural research departments of our country have already obtained in many fields, such as the system development, database, information management system, the application of remote sensing technology, expert system, decision support system, geographic information systems since 1980s. Ying Bo Li (2005) in the study pointed out the meaning of agricultural information service system for the development of agricultural information service, the main body of the agricultural information service to provide agricultural information, to serve the needs of users as the core, in accordance with certain operation rules and system consisting of organic system. Cheng Zhuojie (2007) pointed out that the agricultural information service system for the development of agricultural information service, and agriculture to the modern development as main goal, the agricultural information service subject to provide all kinds of agricultural information as the core, through the main transmission network, and with the help of a variety of information terminal device and the media set up the efficient information transmission system. The two scholars for the understanding of the agricultural information service system has something in common, that is, they think in the agricultural information service system should include the following contents: the main body of the agricultural information service, that is, to provide agricultural information service; agricultural information service object, namely, the need for the agricultural information service of agricultural producers; the contents of agricultural information service: all kinds of agricultural information resources and technology; agricultural information service means: to provide the main body of the agricultural information service must use some means for the demand of service. This paper based on other scholar's understanding of agricultural information service system, and puts forward its own point of view: agricultural information service system is mainly refers to the agricultural information service provider by certain means to provide agricultural information services to the demand side, involved in all aspects of the agricultural information service form the specific content of the system in the analysis.

\section{Current Situation of Agricultural Information Service System Construction of Hubei}

\section{Low Infrastructure Construction}

Table 2-1 and 2-2 show that the fixed telephone popularization rate of $16.97 \%$, mobile phone popularity rate is $76.17 \%$ Internet penetration rate was $43.1 \%$, ranked respectively 17,25 , 19 in the main indicators of information service system construction in Hubei. The broadband access in rural areas household's 144.1 million households, in the position in the ninth. From these data we can draw a conclusion that, compared with the national agricultural information technology has 
developed the advanced provinces and agricultural information service in Hubei Province infrastructure is weak, the Hubei Province agricultural big province status does not match.

Table 2-1: Telecom Service Quality in Parts of China in 2014

\begin{tabular}{|l|l|l|l|l|l|l|}
\hline region & $\begin{array}{l}\text { landline phones } \\
\text { ownership per hundred } \\
\text { persons }\end{array}$ & $\begin{array}{l}\text { ran } \\
\mathrm{k}\end{array}$ & $\begin{array}{l}\text { mobile } \\
\text { ownership per hundred } \\
\text { persons }\end{array}$ & $\begin{array}{l}\text { ran } \\
\mathrm{k}\end{array}$ & $\begin{array}{l}\text { penetration } \\
\text { of internet }\end{array}$ & $\begin{array}{l}\text { ran } \\
\mathrm{k}\end{array}$ \\
\hline Beijing & 41.03 & 1 & 159.53 & 1 & 75.2 & 1 \\
\hline Shanghai & 35.99 & 2 & 132.52 & 3 & 70.7 & 2 \\
\hline $\begin{array}{l}\text { Guangdon } \\
\text { g }\end{array}$ & 29.12 & 4 & 138.16 & 2 & 66 & 3 \\
\hline Fujian & 26.06 & 7 & 114.02 & 5 & 64.1 & 4 \\
\hline Tianjin & 23.96 & 8 & 89.88 & 14 & 61.3 & 5 \\
\hline Zhejiang & 32.4 & 3 & 128.62 & 4 & 60.8 & 6 \\
\hline Liaoning & 27.85 & 6 & 104.41 & 7 & 55.9 & 7 \\
\hline Jiangsu & 28.84 & 5 & 100.03 & 8 & 51.7 & 8 \\
\hline Xinjiang & 22.91 & 9 & 94.24 & 11 & 49 & 9 \\
\hline Shanxi & 16.1 & 20 & 85.55 & 17 & 48.6 & 10 \\
\hline Qinghai & 17.61 & 15 & 93.88 & 12 & 47.8 & 11 \\
\hline Hebei & 15.72 & 22 & 81.91 & 19 & 46.5 & 12 \\
\hline Hainan & 19.39 & 14 & 95.87 & 9 & 46.4 & 13 \\
\hline Shanxi & 20.44 & 11 & 93.32 & 13 & 45 & 14 \\
\hline Shandong & 17.54 & 16 & 85.62 & 16 & 44.7 & 15 \\
\hline $\begin{array}{l}\text { Neimengg } \\
\text { u }\end{array}$ & 15.1 & 23 & 107.73 & 6 & 43.9 & 16 \\
\hline $\begin{array}{l}\text { Chongqin } \\
\text { g }\end{array}$ & 19.54 & 12 & 80.16 & 20 & 43.9 & 17 \\
\hline Ningxia & 16 & 21 & 95.87 & 10 & 43.7 & 18 \\
\hline Hubei & 16.97 & 17 & 76.16 & 25 & 43.1 & 19 \\
\hline Jilin & 21.04 & 10 & 86.22 & 15 & 42.3 & 20 \\
\hline
\end{tabular}

Source: China Statistical Yearbook 2014

Table 2-2: Indexes of Internet Development in Parts of China in 2014

\begin{tabular}{|l|l|l|l|l|l|l|}
\hline region & $\begin{array}{l}\text { penetration of } \\
\text { internet per ten } \\
\text { thousand persons }\end{array}$ & rank & $\begin{array}{l}\text { number of } \\
\text { websites } \\
\text { (unit: ten } \\
\text { thsouand) }\end{array}$ & rank & $\begin{array}{l}\text { Broadband } \\
\text { access users(unit: } \\
\text { ten thsouand) }\end{array}$ & rank \\
\hline Jiangsu & 4095 & 3 & 16.6 & 6 & 575.2 & 1 \\
\hline Zhejiang & 3330 & 5 & 22 & 5 & 540.4 & 2 \\
\hline $\begin{array}{l}\text { Guangdon } \\
\text { g }\end{array}$ & 6992 & 1 & 53.6 & 1 & 518.6 & 3 \\
\hline Shandong & 4329 & 2 & 14.6 & 7 & 448.8 & 4 \\
\hline Hebei & 3389 & 4 & 9 & 10 & 430.4 & 5 \\
\hline Henan & 3283 & 6 & 11.1 & 8 & 301.7 & 6 \\
\hline Fujian & 2402 & 11 & 22.1 & 4 & 240.2 & 7 \\
\hline Sichuan & 2835 & 7 & 11 & 9 & 188.7 & 8 \\
\hline Hubei & 2491 & 8 & 6.4 & 12 & 144.1 & 9 \\
\hline Anhui & 2150 & 12 & 3.8 & 14 & 142 & 10 \\
\hline Hunan & 2410 & 10 & 5 & 13 & 140.2 & 11 \\
\hline Liaoning & 2453 & 9 & 8.6 & 11 & 107.5 & 12 \\
\hline Jiangxi & 1468 & 20 & 2.2 & 21 & 103.9 & 13 \\
\hline
\end{tabular}


Source: China Statistical Yearbook 2014

\section{Unsustainable Development Model}

The process of agricultural information serviceincludes information collection, information integration, information release and to collect user feedback. They are the essential parts of a good job of agricultural information service. Because of the current agricultural information service, there are many problems in every stage, which cannot form a sustainable development model. In the information gathering stage, due to the lack of expert guidance and information accuracy, authority is not guaranteed and collected information lack pertinence and practicability; in information integration phase and collected repeat too much information; information release stage, updated information is not timely, agriculture related information homogenization and due to the lack of credit mechanism and the restraint mechanism in the authenticity of the information cannot be measured, there still exist a lot of problems; in tracking service stage, unable to collect user information feedback, information can only achieve unidirectional flow. The Hubei Province specialized in agricultural information management and service staff, most people are part-time, they are not long-term stationed at the local, limited residence time, continued to be difficult tracking problems may arise in the process of agricultural information technology application and the application of the results.

\section{Less Science Education}

In 2010, Wang Fayuan and Liu Zaizhou took questionnaire survey method to 201 basic agricultural technical staff as the object in Hubei provinceto investigate the current situation of Hubei Province grassroots agricultural extension team. The results showed that in 201 investigation unit, there are 85 County Agricultural Technology Extension Center. Since 2005, each unit each into an agricultural university graduates, and 116 Township agricultural technology extension mechanisms not an agricultural university graduates. Agricultural information service is a high-tech enterprise, which is the core of promoting the development of the cause of high-tech talents. Rural grassroots information service team cannot attract high-quality personnel, which directly hinders the development of agricultural information.

\section{Limited Integration Degree}

The agricultural information service system is composed of the main body of the executive function, including the public service organization, the rural cooperative organization, the enterprise and the individual. These subjects provide agricultural hot news, agricultural technology, agricultural products supply and demand information, agricultural prices and agricultural new policies and regulations, and other services through online method or offline method. Online method refers to the all kinds of agriculture related information to be delivered to farmers through rural information workers, the source of information is mainly notice issued by the superiors. Online method means to convey information through the government, enterprises, and other agricultural information website. Due to the increasing agricultural information websites and information integration degree is not high, resulting in complicated information agriculture and farmer's education level is generally low, leading to the farmers to from the vast amounts of information get their content. In addition, the agriculture information to the managers, the builders and users in the separated state, the agricultural information resources with great dispersion, low degree of sharing, the widespread phenomenon of "information isolated island".

\section{Suggestions of Agricultural Information Service System Construction of Hubei}

\section{Emphasize Infrastructure Construction}

Agricultural information is the main driving force in the development of modern agriculture, construction and improvement of modern agricultural information service system will agricultural information provides an important service guarantee. Therefore, it is necessary to joint forces of the community, and work together to promote the development of agricultural information.The government should not only by the policies and regulations to guide the participation of social forces, must also increase the financial investment, to speed up the construction of infrastructure facilities, so as to lay a foundation for the development of agricultural information service system. 
Besides, we must also comply with the overall planning, orderly construction, the smooth operation of the principle, and to actively strive for social investment, encourage guide telecom operators, it enterprises, scientific research institutions, farmer specialized cooperative organization and other social forces to participate in, widening investment channels, promote the formation of the construction of agricultural information service system in grass roots of the strong force, promote the development of grass-roots agricultural information service system.

\section{Improve Staff Quality}

As basic agricultural information service personnel directly to the farmers to provide agricultural information and technology services group, its scientific and cultural quality of the level of agricultural information service construction has direct effect. Therefore, it is necessary to actively carry out training, improve the quality of information service at the grass-roots level teams. April 15, 2013, the Hubei Provincial People's Government Office issued on implementation of the national rural information demonstration province construction scheme, the scheme proposed the establishment of Hubei rural information service to promote the work of the organization system, the system including leading information system, service system and consultation system. Focus on the construction of 30000 information service site, hiring 10 provincial rural information service strategic consulting experts.

\section{Construct Sharing Mechanism}

The establishment of agricultural database is an important way to realize the sharing of resources. Database construction must pay attention to data quality, it is necessary to do update data and avoid collecting data duplication and ensure data timeliness, authenticity and authority; database of the construction unit should strengthen horizontal communication and improve the efficiency of the data. The government should establish and improve agricultural information resource sharing legal norms and protect farmers to obtain the rights to access the agricultural information.

\section{Acknowledgment}

This work was supported by the grants from "The Research of Agricultural information service system construction to promote agricultural industrialization management” of Wuhan Donghu University Agriculture EC Hubei Provincial Collaborative Innovation Center.

\section{References}

[1] Wang Wei, Song Huiyan, Study on Boundaries and Modelof Multi-bodies Supply ofAgricultural Information Service, J.Journal of Hubei University of Economics. 3(2013) 66 - 70.

[2] Song Huiyan, Wang Wei,Research on Main Body of Agriculture Information Service and its Operation Mode, J.Pioneering with Science \& Technology Monthly.5(2013)29-31.

[3] Mao Haifeng,Research of Agricultural Information Service System in Grassroots, D. Central South University of Forestry \& Technology, 2013.

[4] Zhang Xinmin, Research on Current Situation and Prospect of Agricultural Information Service in China, J. Journal of Hebei Agricultural Sciences.14(2010)106 - 108. 